\title{
PYROPROCESSING TECHNOLOGY DEVELOPMENT AT KAERI
}

\author{
HANSOO LEE, GEUN-IL PARK, KWEON-HO KANG, JIN-MOK HUR, \\ JEONG-GUK KIM, DO-HEE AHN, YUNG-ZUN CHO, and EUNG HO KIM \\ Korea Atomic Energy Research Institute \\ 305-353 Daedukdaero 1045, Yuseong, Daejeon \\ ${ }^{*}$ Corresponding author. E-mail : hslee5@kaeri.re.kr \\ Received July 28, 2011
}

Pyroprocessing technology was developed in the beginning for metal fuel treatment in the US in the 1960s. The conventional aqueous process, such as PUREX, is not appropriate for treating metal fuel. Pyroprocessing technology has advantages over the aqueous process: less proliferation risk, treatment of spent fuel with relatively high heat and radioactivity, compact equipment, etc.

The addition of an oxide reduction process to the pyroprocessing metal fuel treatment enables handling of oxide spent fuel, which draws a potential option for the management of spent fuel from the PWR. In this context, KAERI has been developing pyroprocessing technology to handle the oxide spent fuel since the 1990s. This paper describes the current status of pyroprocessing technology development at KAERI from the head-end process to the waste treatment. A unit process with various scales has been tested to produce the design data associated with the scale up. A performance test of unit processes integration will be conducted at the PRIDE facility, which will be constructed by early 2012. The PRIDE facility incorporates the unit processes all together in a cell with an Ar environment. The purpose of PRIDE is to test the processes for unit process performance, operability by remote equipment, the integrity of the unit processes, process monitoring, Ar environment system operation, and safeguards related activities. The test of PRIDE will be promising for further pyroprocessing technology development.

KEYWORDS : Spent Nuclear Fuel, Pyroprocessing, Head-end, Oxide Reduction, Electrorefining, Electrowinning, Waste Treatment

\section{INTRODUCTION}

Pyroprocessing was originally developed for the recycling of the metal fuel from a fast reactor. It was noted that pyroprocessing can be modified by an oxide reduction process enabling treatment of spent nuclear fuels from a commercial light water reactor (LWR) which is in an oxide form. Pyroprocessing treatment can reduce the volume, radioactivity, and heat load of the LWR spent fuels [1]. In addition, pyroprocessing based on the group recovery of TRU can provide metal fuels for the sodium cooled fast reactor while keeping intrinsic proliferation resistance.

KAERI has been developing pyroprocessing since 1997. The concept development, bench scale testing, and laboratory scale key unit process demonstration were carried out by 2006. From 2007 to 2011, the focus moved to the design and construction of an engineering scale integrated system. The PyroProcess Integrated inactive Demonstration facility (PRIDE) will be constructed by early 2012.
The process flow diagram consists of head-end processes (decladding, voloxidation, oxide feed preparation), electrochemical processes (oxide reduction, electrorefining, electrowinning), and waste treatment processes as shown in Fig. 1.

\section{UNIT PROCESS OF PYROPROCESSING}

\subsection{Head-end Process}

The head-end process in pyroprocessing converts spent fuel assembly into a suitable feed material supplied to the oxide reduction process, and molten salt processes recover uranium and TRU from spent fuel material. The head-end process has four unit processes, which involves a disassembling process for the removal of the upper end fitting from the spent fuel assembly, a cutting process of extracted spent fuel rods and a decladding process for separation of spent fuel materials, a voloxidation process 


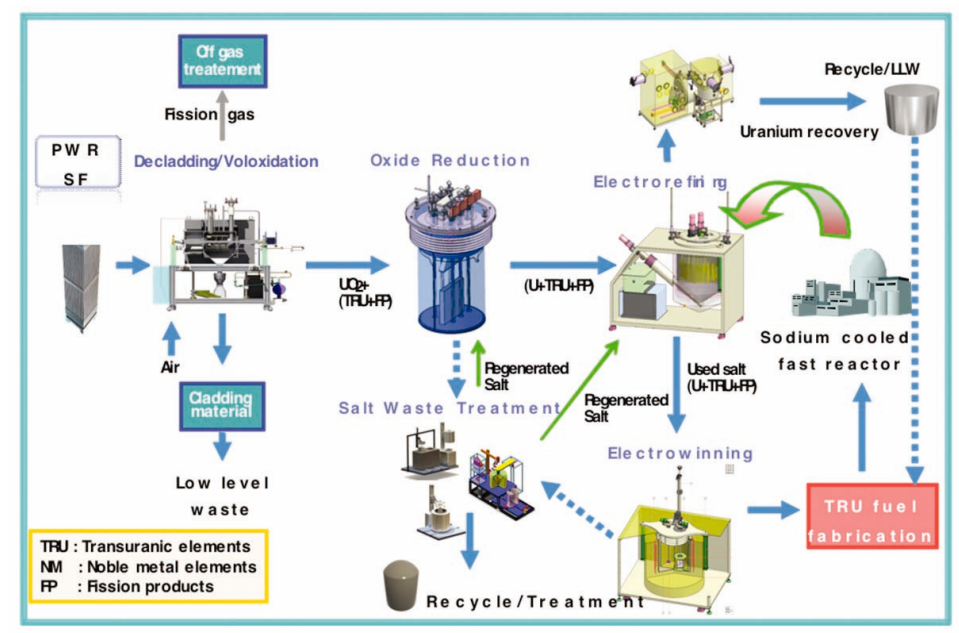

Fig. 1. Flow Diagram of Pyroprocessing (KAERI).

as the final step to fabricate raw material for pyroprocessing. Waste treatment in the head-end process is considered, especially the recovery of volatile and semi-volatile fission products.

\subsubsection{Disassembling, Rod Extraction and Cutting Process}

The first step of the head-end process is to disassemble the spent PWR fuel assembly, and to extract fuel rods, followed by cutting fuel rods of $\sim 4 \mathrm{~m}$ into rod-cuts in the proper size for the decladding process. Disassembling, extraction and cutting operations of actual spent PWR fuel assembly have been conducted in a laboratory scale for a PIE and DUPIC (Direct Use of PWR spent fuel in CANDU) experiment in PIEF.

In the disassembling test, the wrench unfastened the securing nuts of the bottom nozzle so that the remote manipulator could remove the bottom nozzle from the fuel assembly. A tele-operated manipulator system was employed in the disassembling system for handling and disassembling of a spent fuel. From the results of the verification tests, the position control value was controlled within a $0.5 \mathrm{~mm}$ error [2].

The rod extractor consists of a clamping table, an extraction rotary head, a cradle, and a side transfer. The fuel rods are extracted one by one from the fuel assembly by grasping and pulling the end caps using a rod gripper [3]. The experimental results showed that the rod extraction device exhibited an extraction rate of about $92 \%$. In addition to the extraction of fuel rods, the bottom nozzle, nuts and pins were also removed successfully by using the rod extractor.

The rod cutting tests were performed with diamond wheel cutting and tube cutting methods, which indicated that the tube cutting was more suitable than the diamond wheel cutting method due to its advantages in durability, maintainability of the tube circle, debris generation, and risk of fire.

\subsubsection{Decladding Process}

The decladding step in the head-end process is essential in determining the recovery efficiency of spent fuel material from a cladding tube. Mechanical decladding by slitting and oxidative decladding among several technologies have been intensively developed for high decladding efficiency.

A mechanical decladding process with slitting technology was developed for the DUPIC fuel fabrication process. The decladding efficiency for spent fuel with a burn-up of less than $35,000 \mathrm{MWd} / \mathrm{tU}$ was $99 \%$, whereas that for a burn-up of $60,000 \mathrm{MWd} / \mathrm{tU}$ was decreased to $74 \%$ due to the interaction of contact between the pellet and cladding.

In order to enhance the decladding efficiency for high burn-up spent fuel, the oxidative decladding efficiency without a rotation mode was experimentally evaluated based on the results of a hot cell performance test. The decladding efficiency was close to $100 \%$ for spent fuel with a burn-up of less than $40,000 \mathrm{MWd} / \mathrm{tU}$ when oxidative decladding with rod-cuts of less than $30 \mathrm{~mm}$ was performed at $500^{\circ} \mathrm{C}$ for $10 \mathrm{~h}$. On the other hand, spent fuel with a burn-up higher than 50,000 $\mathrm{MWd} / \mathrm{tU}$ showed low decladding efficiency of about $15 \%$ due to a small fuelto-clad gap and low oxidation rate. An improved decladding efficiency of higher than $99 \%$ for the high burn-up spent fuel required an oxidation time longer than $20 \mathrm{~h}$ at $700^{\circ} \mathrm{C}$. Therefore, an oxidative decladder with a rotational device was required to reduce the oxidative decladding time and obtain a very high decladding efficiency. 

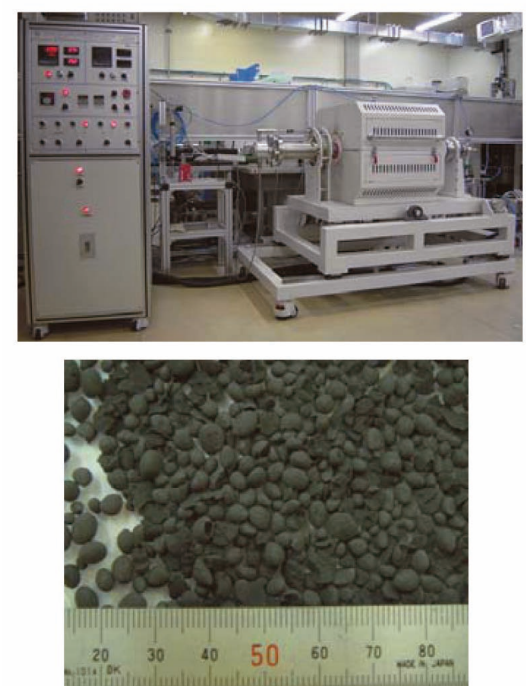

Fig. 2. A Rotary Voloxidizer (Left) and $\mathrm{UO} 2_{+\mathrm{x}}$ Granules (Right)

\subsubsection{Oxide Feed Fabrication Process}

Uranium oxides of shapes, such as powder and crushed pellets, were tested for the oxide reduction process [4-6]. Although $\mathrm{U}_{3} \mathrm{O}_{8}$ powder has advantages in terms of current efficiency, it is difficult to handle and requires a well designed cathode basket $[4,5]$. The current efficiency of crushed pellets was lower than that of $\mathrm{U}_{3} \mathrm{O}_{8}$ powder [6]. Fine powder less than $45 \mu \mathrm{m}$ during the preparation of crushed pellets was produced from crushing the rod-cut [6]. Based on the above characteristics, feed material for the oxide reduction process needs to satisfy the following characteristics: (1) a porous solid structure with fine crystallite for rapid reduction time and high reduction extent, (2) a solid structure with continuously bonded crystallites permitting strength for safe handling and solid shape with high packing density, and (3) a solid structure prohibiting salt carryover and contamination of salt baths. Feed material forms, such as granules and porous pellets, were considered to enhance the current efficiency of electrochemical processes. Fission gases and semi-volatile fission products during feed material fabrication are vaporized and removed to reduce the burden of fission products on the electrochemical processes.

The particles in $\mathrm{U}_{3} \mathrm{O}_{8}$ powder during oxidation were bonded together and transformed into an aggregate above $1000^{\circ} \mathrm{C}$. A rotary kiln was typically used to mix powder and calcine granules by a tumbling motion. In 2009, a laboratory scale rotary voloxidizer (max. $1.5 \mathrm{~kg} \mathrm{U}_{3} \mathrm{O}_{8}$ powder/batch) as shown in Fig. 2 was designed and manufactured to investigate particle size controllability for $\mathrm{U}_{3} \mathrm{O}_{8}$ powder. The fabrication characteristics of granules from $200 \mathrm{~g} \mathrm{U}_{3} \mathrm{O}_{8}$ powder was investigated in terms of thermal treatment temperature of 1150 to $1200^{\circ} \mathrm{C}$ in an Ar atmosphere, with a time of 5 to $15 \mathrm{~h}$, and a

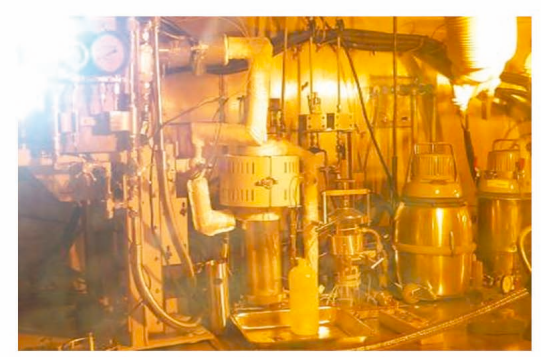

(a) Sintering off-gas trapping system

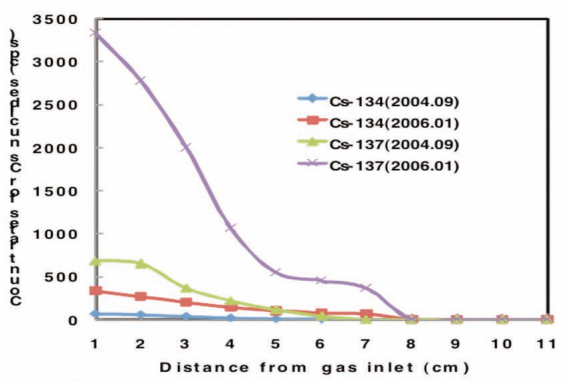

(b) Gamma Spectroscopy Measurement

Fig. 3. Off-gas Treatment System for the DUPIC Sintering Furnace in the DFDF and Gamma Spectroscopy Measurement Results of the Fly ash Filter

rotational velocity of 1 to $3 \mathrm{rpm}$ using a rotary voloxidizer. The recovery rate of granules higher than $1 \mathrm{~mm}$ with $\mathrm{UO}_{2+\mathrm{x}}(0.25<\mathrm{x}<0.67)$ composition (Fig. 2) significantly increased with an increasing temperature, rotation velocity and time of up to $10 \mathrm{~h}$. The typical recovery rate of granules showed about $89 \%(>1 \mathrm{~mm})$ and $98 \%(>0.5 \mathrm{~mm})$. The $\mathrm{UO}_{2}$ granule with a density of $4.38 \mathrm{~g} / \mathrm{cm}^{3}$ (40\% TD) was fabricated by reduction of $\mathrm{UO}_{2+\mathrm{x}}$ at $1000^{\circ} \mathrm{C}$ for $5 \mathrm{~h}$ in a $4 \% \mathrm{H}_{2}$-Ar atmosphere.

The performance of the engineering scale rotary voloxidizer for feed material fabrication to be installed in PRIDE will be demonstrated using simulated fuel pellets. Porous pellets might be easily fabricated by traditional sequential process of milling, compaction, and sintering using the $\mathrm{U}_{3} \mathrm{O}_{8}$ powder obtained by oxidative decladding.

\subsubsection{Off-gas Treatment Process}

An off-gas treatment system for trapping fission products released from the oxide feed fabrication process is very important for protecting against the release of nuclides into the environment. In the middle of the $1990 \mathrm{~s}$, research on the trapping of cesium released from the OREOX and sintering processes started in fabricating DUPIC fuel [7]. An off gas treatment system for trapping both volatile fission gases, such as $\mathrm{H}-3$ and I in an OREOX process and $\mathrm{Cs}$ in a sintering process was established at the DFDF (DUPIC Fuel Development Facility) as shown in Fig.3 (a). It was demonstrated that released Cs from the sintering process was completely trapped by fly ash filters. 
Fig. 3 (b) shows gamma spectroscopy measurement results of the fly ash filter.

Joint research for treating off-gases generated from the voloxidation processwas performed through the I-NERI project with INL from 2004 to 2010 [8,9]. A performance test of off-gas treatment unit installed in INL HFEF (Hot Fuel Examination Facility was performed using a fly ash filter, a calcium-based filter, and $\mathrm{AgX}$. Through this experiment, although the experimental batch size was small $(100 \mathrm{~g}-\mathrm{HM} / \mathrm{batch})$, it was confirmed that even in a vacuum condition of less than 1 Torr, Cs was efficiently trapped by the fly ash filter, Tc by a calcium based filter and I by a silver-impregnated zeolite filer. This result showed the feasibility of selective trapping of major release nuclides such as Cs, Tc, and I [10].

\subsection{Oxide Reduction}

The oxide reduction process based on the electrochemical reduction in a $\mathrm{LiCl}-\mathrm{Li}_{2} \mathrm{O}$ electrolyte has been developed for the volume reduction of PWR spent fuels and for providing metal feeds for the electrorefining process. During the oxide reduction process, high heat load fission products dissolved into the chloride molten salt resulting in a decrease of the heat load of spent fuels. Additionally, the metallization of oxides to more dense metals enables the volume reduction of spent fuels. The metal products produced by the oxide reduction process can be directly transferred to the electrorefining process as feed materials. One issue of concern is the concomitant transfer of residual salts in the metal products to the electrorefining process. The residual salts from the oxide reduction process, $\mathrm{LiCl}-$ $\mathrm{Li}_{2} \mathrm{O}$, would cause the formation of $\mathrm{UO}_{2}$ and the breaking of the eutectic composition in the electrorefining salt, LiCl-KCl. To solve this incompatibility of salts between oxide reduction and electrorefining, cathode processing was devised for the removal of residual salts in the metal products from the oxide reduction process. The recovered salts from the cathode processor can be regenerated in the waste salt treatment process as shown in Fig. 4.

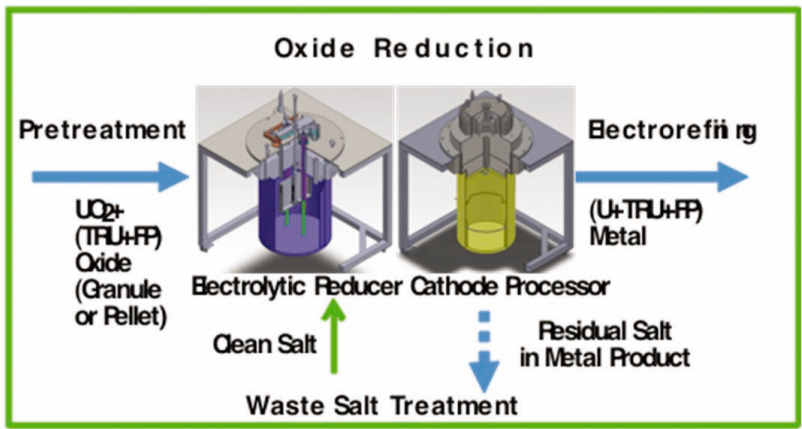

Fig. 4. Oxide Reduction System.

\subsubsection{Development of the Electrolytic Reduction Process}

Inspired by the recent development of electrochemical reduction technology for the metallization of oxides to valuable metals, there have been several attempts to realize the electrochemical reduction technology for the reduction of spent fuels [11-12]. The electrochemical reduction process for spent fuels operates in a bath of molten $\mathrm{LiCl}$ at $650^{\circ} \mathrm{C}$ with small quantities of dissolved $\mathrm{Li}_{2} \mathrm{O}$ or $\mathrm{CaCl}_{2}$ at about $850^{\circ} \mathrm{C}$ with small quantities of dissolved $\mathrm{CaO}$. In this electrochemical reduction process, the oxide spent fuel is made as a cathode. The reaction mechanism is known to proceed via direct removal of oxygen ions from the oxide cathode or chemical reaction with in-situ generated $\mathrm{Li}$ from $\mathrm{Li}_{2} \mathrm{O}$ or $\mathrm{Ca}$ from $\mathrm{CaO}$. Generally, the $\mathrm{LiCl}-\mathrm{Li}_{2} \mathrm{O}$ molten salt has been used as a reaction medium of the oxide reduction process mainly considering the relatively lower reaction temperature.

With the progress of electrolytic reduction reaction, the oxide ions from the oxide spent fuel contained in the cathode basket is evolved as gas on the anode leaving the metal spent fuel in the cathode basket. During the electrolytic reduction process, alkali and alkali earth elements are dissolved into the molten salt. Lanthanides, except $\mathrm{Eu}$ and metallic fission products of spent nuclear fuels, remain in the cathode.

The design of the laboratory scale electrolytic reducer was conducted after the calculation of the potential distribution on the anode/cathode/molten salt by the modeling and optimization of the shape of the anodes. The results led to the deduction of the optimized electrolytic reduction conditions which can prevent the dissolution of Pt anodes and minimize the current losses. The construction of a newly designed laboratory scale electrolytic reduction system $\left(20 \mathrm{~kg} \mathrm{UO}_{2} / \mathrm{batch}\right)$ was completed in 2009 and inactive demonstration was performed and showed high reduction yields up to $99.5 \%$.

The stability of the Pt anodes mainly depends on the concentration of $\mathrm{Li}_{2} \mathrm{O}$ in the molten salt $\left(\mathrm{Li}_{2} \mathrm{O}<0.6 \mathrm{wt} \%\right.$ $\rightarrow$ local corrosion resulting in the formation of $\mathrm{Li}_{2} \mathrm{PtO}_{3}$, $\mathrm{Li}_{2} \mathrm{O}<0.3 \mathrm{wt} \% \rightarrow$ uniform corrosion resulting in the dissolution of the $\mathrm{Pt}$ ).

The formation of corrosion products and their growth from the construction materials in the electrolytic reduction conditions were elucidated. For Inconel 600 having $74 \mathrm{Ni}-16 \mathrm{Cr}-8 \mathrm{Fe}$ composition, the corrosion products were $\mathrm{NiO}, \mathrm{Fe}_{2} \mathrm{O}_{3}$ at the initial stage, $\mathrm{NiO}, \mathrm{Cr}_{2} \mathrm{O}_{3}, \mathrm{NiFe}_{2} \mathrm{O}_{4}$, and $\mathrm{NiCr}_{2} \mathrm{O}_{4}$ at the propagation stage, and transformation of $\mathrm{NiFe}_{2} \mathrm{O}_{4}$ to $\mathrm{NiCr}_{2} \mathrm{O}_{4}$ at the growth and formation stages. The quantitative and long term corrosion data were obtained. The local corrosion was suppressed by the prevention of the internal diffusion of oxygen ions by $\mathrm{Ni}$ rich oxygen active oxides.

The formation of $\mathrm{Li}_{2} \mathrm{REO}_{2}$ by a reaction between rare earth oxides and $\mathrm{Li}_{2} \mathrm{O}$, and the effects of a critical 
concentration of $\mathrm{Li}_{2} \mathrm{O}$ on the generation of $\mathrm{Li}_{2} \mathrm{REO}_{2}$ were evaluated and quantitative data was produced. $\mathrm{RE}_{2} \mathrm{O}_{3}$ was metallized via indirect electrolysis only under a very low activity of $\mathrm{Li}_{2} \mathrm{O}$. Using the selective dissolution characteristics of metal by $\mathrm{Br}_{2}$, the reduction yield of 8 rare earth oxides were measured as a function of initial $\mathrm{Li}_{2} \mathrm{O}$ concentrations. For the reduction of $\mathrm{LiYO}_{2}$, the $\mathrm{Li}_{2} \mathrm{O}$ concentration should be below $1.9 \mathrm{wt} \%$ to decompose into $\mathrm{Li}_{2} \mathrm{O}$ and $\mathrm{Y}_{2} \mathrm{O}_{3}$ and then the $\mathrm{Li}_{2} \mathrm{O}$ concentration should be further lowered below the critical $\mathrm{Li}_{2} \mathrm{O}$ concentration for $\mathrm{Y}_{2} \mathrm{O}_{3}$ reduction.

The reaction behaviors of lithium metal compounds ( $\mathrm{LiI}, \mathrm{LiBr}$ and $\mathrm{Li}_{2} \mathrm{Se}$ ) on the anode/cathode were analyzed in molten $\mathrm{LiCl}-\mathrm{Li}_{2} \mathrm{O}$. $\mathrm{Se}^{2-}$ damaged the Pt anodes with the formation of $\mathrm{PtSe}_{2} . \mathrm{Br}_{2}$ formation from $\mathrm{Br}^{-}$is a reversible reaction and $\mathrm{I}_{2}$, the oxidation product of $\mathrm{I}^{-}$, reacts with $\mathrm{I}^{-}$ to form $\mathrm{I}^{3-}$.

Based on the laboratory scale demonstration results, the engineering scale electrolytic reducer was constructed in 2011 and the inactive demonstration will be carried out from 2012 at PRIDE.

\subsubsection{Development of Cathode Processor}

After the electrolytic reduction process, the residual salt in the cathode basket amounts to $\sim 20 \mathrm{wt} \%$ of the metal products. The cathode process for the removal of residual salts in the cathode basket of the electrolytic reducer can ease the burden of the electrorefining process. The recovered salt in the cathode processor is treated in the waste salt regeneration process and then recycled to the electrolytic reduction process.

The operation of the cathode processor is based on the vaporization in a vacuum condition. The interactions between salt/fission products, salt/salt, salt/rare earth oxides, and salt/metals were investigated. The reoxidation of uranium metals with the reaction of $\mathrm{Li}_{2} \mathrm{O}$ in the residual salts can occur above $\sim 940^{\circ} \mathrm{C}$. Accordingly, the heating temperature for the cathode processor was determined to be lower than that temperature.

In 2010, a laboratory scale cathode processor $(4 \mathrm{~kg}$ $\mathrm{LiCl} /$ batch) was installed. This equipment is characterized by the maximization of the temperature difference between a heating crucible and a receiving crucible. The salt recovered in the receiving crucible is in a powder form, which is easy to handle in a remote operation condition excluding the necessity of hot molten salt transfer. The principle is the condensing of $\mathrm{LiCl}$ vapor as a solid in the cold region of the cathode processor. In an experiment of reduced pressure $(-20 \mathrm{inHg})$ at $900^{\circ} \mathrm{C}$, more than $99 \%$ of the salts were evaporated and nearly $100 \%$ were recovered in the receiving crucible.

The engineering scale cathode processor was constructed in 2011 and remote operation tests in the mock-up facility are going on before its installation at PRIDE.

\subsection{Electrorefining Process}

Electrorefining, a pyrochemical process to recover pure uranium from a metallic or electrolytically reduced spent fuel, is one of the most important processes in pyroprocessing, which means a process without any aqueous solution to recover useful elements such as uranium $(\mathrm{U})$ and plutonium $(\mathrm{Pu})$ from spent nuclear fuels. During the electrorefining process, the reduced metal composed of $U$, transuranic element (TRU) and rareearth element (RE) is dissolved into $\mathrm{LiCl}-\mathrm{KCl}$ eutectic salts, whereas only $U$ is recovered as a pure dendritic form on a solid cathode in the electrorefining process. The remaining $\mathrm{LiCl}-\mathrm{KCl}$ eutectic salt containing the accumulated TRU and RE is transferred to electrowinning process.

\subsubsection{High-throughput Electrorefining System}

The high-throughput electreorefining system (HTES) is composed of an electrorefiner, a salt distiller, and a melting furnace for uranium ingot casting. The Uchlorinator ( $\mathrm{UCl}_{3}$ making equipment) and transportation system are also contained in the HTES. The electrorefiner used a graphite electrode, so uranium dendrites are deposited and fall down from the electrode spontaneously [13], and finally collected at the bottom of the reactor. The collected uranium deposits are withdrawn with a bucket-type transfer. The uranium deposits are fed into a salt distiller, and the residual salt within the uranium deposits is distilled, and then salt-removed uranium dendrite is melted and consequently reformed to ingots for storage or for future use. The engineering-scale HTES was designed for PRIDE (PyRoprocess Integrated inactive DEmonstration facility).

\subsubsection{Electrorefiner}

A throughput of the electrorefining process should be enhanced to treat the spent fuel commercially. To increase the throughput, the lab-scale electrorefiner (ER), which has a self-scraping concept using graphite cathodes with a capacity of $20 \mathrm{kgU} / \mathrm{batch}$, was installed as shown in Fig.5. In this ER, 24 graphite cathodes were installed and the anode was designed to be loaded up to $50 \mathrm{~kg}$ metal into an anode basket. The throughput of the ER was verified by the current-potential curves. The key factors that affect those curves are the surface area of the anode, which is related to the amount of the anode load and $\mathrm{UCl}_{3}$ concentration in $\mathrm{LiCl}-\mathrm{KCl}$ salt. As the amount of the anode load and $\mathrm{UCl}_{3}$ concentration increase, the current corresponding to the potential increases. For a high throughput of the ER, a high current should be applied, but the current was limited by the cut-off potential of the anode $(0.4 \mathrm{~V}$ vs. $\mathrm{Ag} / \mathrm{AgCl})$ because of noble metal retention in the anode basket [14]. When $32 \mathrm{~kg} \mathrm{U}$ metal was loaded into the anode basket and the $\mathrm{UCl}_{3}$ concentration was $5.8 \%$ in the $\mathrm{LiCl}-\mathrm{KCl}$ salt, the upper current limit 


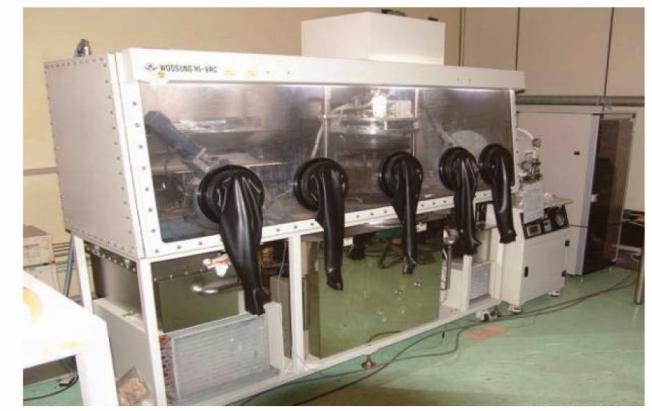

Fig. 5. High-throughput Electrorefiner Equipped with Graphite Cathodes

was 325 A by extrapolation. As the current efficiency of this ER was $80 \%$, the throughput was $17.9 \mathrm{~kg} \mathrm{U}$ in a day. If more than $40 \mathrm{~kg}$ of metal pellets are loaded into the anode basket and the $\mathrm{UCl}_{3}$ concentration is more than $8 \%$, the upper current limit may be more than $400 \mathrm{~A}$ and the $20 \mathrm{~kg} \mathrm{U} /$ batch throughput of the ER can be easily achieved.

\subsubsection{Salt Distillation}

Uranium deposits generated from the electrorefiner contain about $30 \mathrm{wt} \%$ of salt. The uranium deposits should have less than $1 \mathrm{wt} \%$ of salt for the preparation of uranium ingots in the following ingot casting process. A vacuum evaporation technique was applied to the salt removal system and the behavior of the salt evaporation from uranium deposits with a small-scale experimental set-up was studied. It was found that the vacuum pressure and the hold temperature are the key factors of the evaporation process. The evaporation rate of the salt increases exponentially with the system temperature since the vapor pressure increases rapidly with the temperature. From the experimental results of the above study, an engineering scale salt distiller was developed with a capacity of $50 \mathrm{~kg}$ $\mathrm{U}$ deposit/day. The salt distillation system is composed of a distillation tower, a cooler, and a vacuum system. The evaporation zone of the distillation tower is separated with a condensing zone by a heat shield.

\subsubsection{Uranium Ingot Casting}

In the ingot casting process, the salt-removed uranium deposit, dendrite, is finally consolidated into a solid cylindrical metallic form, which will be used as raw material for sodium fast reactor (SFR) fuel or will be stored for future use. The ingot casting equipment, a kind of melting furnace, consists of a vacuum chamber, a charger, a crucible and a mold. The uranium dendrite is fed to the charger and the uranium dendrite is placed into the crucible, which is made of graphite coated with zirconia. An induction coil heater in a vacuum chamber is operated at $1300^{\circ} \mathrm{C}$. The uranium dendrite is melted and then tilted into the graphite mold. The multiple 8 molds were installed to be rotated for producing ingots. To improve the safety of operation in a hot cell, a new cooling concept without water was introduced in the heating system. The outer maximum temperature of the induction coil heater without water-cooling reached $480^{\circ} \mathrm{C}$ for $\mathrm{Cu}$ melting at $1300^{\circ} \mathrm{C}$, which shows good applicability of the induction coil heater without a water cooling system for uranium casting equipment [15].

\subsubsection{Uranium Chlorination}

Uranium tri-chloride $\left(\mathrm{UCl}_{3}\right)$ is added to the electrorefiner to remove unreduced lanthanide oxides in the anode basket of the electrorefiner as well as to stabilize the initial cell voltage between the electrodes in the electrorefining reactor. The uranium chlorination process is composed of two steps: 1) a reaction of gaseous chlorine with liquid cadmium to form the $\mathrm{CdCl}_{2}$ in the Cd layer, 2) a reaction of $\mathrm{U}$ with $\mathrm{CdCl}_{2}$ in $\mathrm{LiCl}-\mathrm{KCl}$ eutectic salt to produce $\mathrm{UCl}_{3}$. The chlorination apparatus has a capacity of $1.3 \mathrm{~kg}$ $\mathrm{UCl}_{3} /$ batch, and consists of a chlorine gas feeder, a chlorinator, a wet scrubber for off-gas treatment, and a pelletizer. The prepared $\mathrm{UCl}_{3}$ salt in $\mathrm{LiCl}-\mathrm{KCl}$ eutectic salt is transferred to solidify to form a pellet, which can be supplied easily to the electrorefiner. The engineeringscale uranium chlorinator with a capacity of $30 \mathrm{~kg}-\mathrm{U} / \mathrm{batch}$ is now designed for PRIDE.

\subsubsection{Molten Salt Transport}

After electrorefining, the residual molten salt is transported to the electrowinning system in order to recover U/TRU/RE, thus a molten salt transfer system [16] by suction is now being developed. Experimental apparatus was designed and installed. The performance test is being carried out.

\subsection{Electrowinning System}

The electrowinning technique using a liquid cadmium cathode (LCC) is a key step for a non-proliferation because TRU can be co-deposited with uranium on liquid cadmium. During the electro-deposition of U/TRU elements, however, the $\mathrm{U}$ ion was known to be deposited in the shape of dendrite on the surface of the liquid cathode [17]. This U dendrite hinders a co-deposition of the $U$ and TRU elements, so a paddle-type stirrer [18] and a pounder agitator [19] were developed to prevent the formation of $U$ dendrites on the LCC in Japan and the United States.

A Residual Actinides Recovery (RAR) process has been developed by combining electrolysis using an LCC to collect most of the residual actinides in a spent salt and oxidation of a part of the RE fission products co-deposited onto an $\mathrm{LCC}$ by a $\mathrm{CdCl}_{2}$ oxidant.

Effective analytical technologies using the absorption spectrophotometry and characterizing CV data for lanthanides and actinides in the molten salt have been 


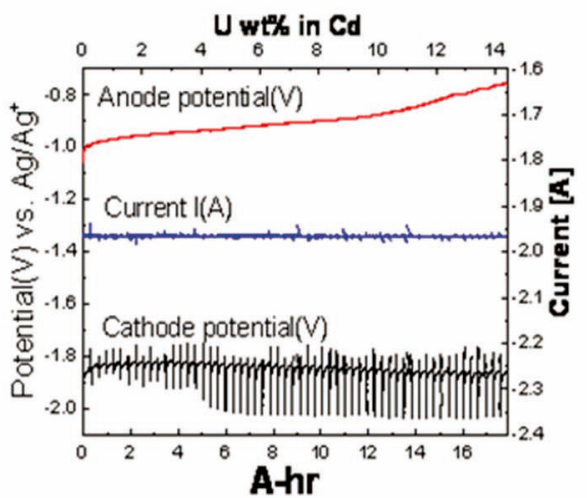

(a) Change in anode and cathode potential

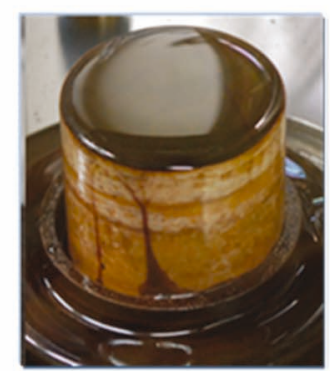

(b) No dendrite growth out of crucible

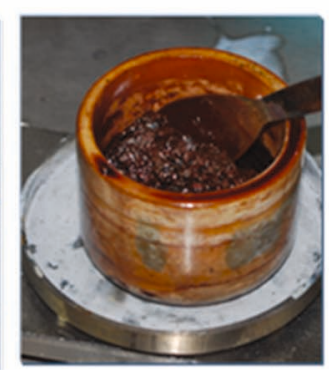

(c) U deposits in the $\mathrm{Cd}$

Fig. 6. LCC Performance Result using the Mesh Agitator

developed. In addition, the development of a computational model using a comprehensive modeling approach is currently under investigation to simulate the more realistic electro-fluid dynamics features of an electrowinning cell.

\subsubsection{U Deposition Result using an Automatically- operated Mesh-type LCC Assembly}

A mesh-type LCC assembly has been developed to prevent $\mathrm{U}$ deposits from growing into dendrites. In this study, an electro-deposition experiment of $U$ on LCC in the $\mathrm{LiCl}-\mathrm{KCl}$ molten salt electrolyte was carried out to evaluate the performance of the mesh agitator. When $U$ deposits are formed on the LCC surface during the electrodeposition, the mesh agitator pushes the $U$ deposits into the $\mathrm{Cd}$. $\mathrm{U}$ deposits will be sunk into the liquid $\mathrm{Cd}$ by the grid of the mesh, while the liquid $\mathrm{Cd}$ will penetrate through the opening of the mesh. Finally, most of the $U$ deposits will gather on the bottom of the LCC crucible.

Fig. 6 shows the potential profiles against the reference electrode ( $\mathrm{LiCl}-\mathrm{KCl}-1 \mathrm{wt} \% \mathrm{AgCl}$ ) during the electrodeposition of $U$ metal on LCC. A constant current of 100 $\mathrm{mA} / \mathrm{cm}^{2}$ was applied throughout the experiment. The periodic fluctuations of the cathode potential are due to the change of the cathode surface area during the mesh operation where a mesh is made of stainless steel (STS) and so the total cathode surface area changes by the contacting of the STS mesh with the Cd. After the mesh returned to the initial position, the cathode potential also returned to the potential level before the mesh pushed the $\mathrm{Cd}$. If the stabilized potential continuously increases positively when compared with the previous one, it shows the growth of $U$ dendrites on the LCC. In this study, there was no increase in the stabilized cathode potential throughout the experiment. After the termination of the $\mathrm{U}$ deposition experiment, no dendrite had grown out of the crucible and most of the $U$ deposits were sunk on the bottom of the LCC crucible as shown in Fig. 6. In this experiment, $\mathrm{U}$ was collected to $14 \mathrm{wt} \% \mathrm{U} / \mathrm{Cd}$ without the dendrite growth out of the crucible. This indicates that the mesh agitator can effectively hinder the growth of $U$ dendrites.

\subsubsection{Residual Actinides Recovery}

A RAR process was developed by combining the electrolysis using LCC to collect most of the residual actinides in a spent salt phase and oxidation of a part of the rare earth fission products co-deposited onto an LCC by a $\mathrm{CdCl}_{2}$ oxidant [20]. The same equipment with an LCC electrowinning can be used for the RAR operation. Therefore, the RAR process has promising merits, such as using compact equipment and a simple process fitted for use in a hot cell by MSM operation [21].

The selective recovery features of actinide metals from the Cd-U alloy prepared in the RAR test were investigated. The rate of $\mathrm{UCl}_{3}$ formation from the $\mathrm{Cd}-\mathrm{U}$ alloy is very slow compared to that from $\mathrm{U}$ metal in the $\mathrm{LiCl}-\mathrm{KCl}$ salt because of the LCC structure. As a result of the reaction of uranium metal in the $\mathrm{LCC}$ with a $\mathrm{CdCl}_{2}$ oxidant, $\mathrm{UCl}_{3}$ could be generated in the $\mathrm{LiCl}-\mathrm{KCl}$ salt phase by stirring. However, the rate of $\mathrm{UCl}_{3}$ formation was very slow compared to that of the direct reaction of uranium metal with $\mathrm{CdCl}_{2}$.

One of the various driving forces affecting the selective recovery of actinides in the RAR system originates from the density difference of salt and cadmium and metals to be collected, such as RE and actinides. Metals deposited onto the LCC can be divided into two (upper and lower) positions of the cadmium except for being dissolved in the cadmium medium. Most RE metals exist at the interface between salt and cadmium due to their densities being lower than cadmium, but actinide metals such as uranium and TRU can be precipitated in the form of uranium metal particles or TRU metal-cadmium intermetallic compounds below the liquid cadmium metal due to their 
density being higher than cadmium. Thus, the selective oxidation behavior of the $\mathrm{RE}$ by a $\mathrm{CdCl}_{2}$ oxidant dissolved in salt could be preferred because the cadmium pool acts as a barrier to prevent contacting the $\mathrm{CdCl}_{2}$ oxidant with actinide metals.

\subsubsection{In Situ Analysis Technology}

To practically use the recovered actinides as a SFR fuel [22], it is necessary to protect the co-deposition of lanthanide elements. Therefore, it is necessary to understand the chemical behavior of lanthanides in molten salt in order to efficiently avoid the co-deposition of lanthanide elements and to further improve the efficiency of the electrowinning process. For this purpose, an effective analytical technique for lanthanides and actinides in the molten salt is desired.

Absorption spectrophotometry, which provides information about the change of the chemical status of complexes through a change in the electronic absorption spectrum, is an adequate technique. Some properties such as the standard potential, diffusion coefficient, and activity coefficient have been investigated by an electrochemical technique. A general method for characterizing $\mathrm{CV}$ data includes non-linear curve fittings of multiple CV curves obtained at different scan rates over a wide range of timescales [23].

\subsubsection{Computational Model Development}

A comprehensive modeling approach with the pertinent algorithm has been developed to simulate the more realistic electro-fluid dynamics features of an electrowinning cell. The throughput and separation performance is determined by the cell configuration, operating conditions, and the chemical state of the electrolytic cell. A 3-D electrochemical modeling in a framework of Computational Fluid Dynamics (CFD) [24] code has been proposed and dealt with in detail to simulate the electro-transport behavior that appears in a molten-salt electrowinning system. The modeling approach in this study foucuses on the mass transport and current density associated with the concentration and the surface over potential based on a cell configuration and the moltensalt electrolyte turbulence. The electrowinning cell model simulated here has a structure composed of a LCC crucible and two shrouded anodes. This implementation with a unique feature of the potential-to-current algorithm could provide useful information for more realistic spatial variation of the electrochemical characteristics.

\subsection{Waste Treatment Process}

\subsubsection{Metal Waste Treatment Process}

Metal wastes generated from the head-end process of spent fuel are mainly composed of cladding hulls and structural parts. A trace of actinides, such as $\mathrm{U}, \mathrm{Pu}, \mathrm{Am}$, and $\mathrm{Cm}$, and FPs (Fission Products) penetrate into the inner layer of zircaloy cladding hulls. Structural parts that include tie plates, springs, spacer grids, guide tubes, spacers, etc. made of various stainless steels, Inconel, and zircaloys, are also activated, which results in the generation of Co60 by neutrons created during the fuel irradiation process in the reactor. Table 1 shows the amount of metal waste by volume and mass before and after the treatment. It was assumed that the stacking density of the cladding hull was $980 \mathrm{~kg} / \mathrm{m}^{3}$ and the actual density of the cladding hull ingot after induction melting was $80 \%$ of the theoretical density. In addition, the volume reduction of the fuel hardware by 500 ton compaction was assumed to be $1 / 8$.

Various treatment technologies that have been studied for the disposal of cladding hull/hardware waste can be categorized as mechanical, thermo-mechanical and chemical processes. The process is divided into several methods depending on the use of matrices, which include 1) encapsulation, 2) compaction and encapsulation, 3) matrix formation (with or without compaction), 4) melting (with or without cleaning), 5) chemical reaction to chlorides, fluorides, oxides, or sulfates, and encapsulation, 6) conversion into an absorbent for high level waste and encapsulation [25].

Table 1. Composition of Pretreatment Process Waste (10 ton/HMTU)

\begin{tabular}{c|c|c|c|c|c|c|c|c}
\hline & \multicolumn{4}{|c|}{ As generated } & \multicolumn{4}{c}{ After treatment } \\
\cline { 2 - 9 } & $\begin{array}{c}\text { Mass } \\
(\mathrm{kg})\end{array}$ & $\begin{array}{c}\text { Composition } \\
(\%)\end{array}$ & $\begin{array}{c}\text { Volume } \\
\left(\mathrm{m}^{3}\right)\end{array}$ & $\begin{array}{c}\text { Composition } \\
(\%)\end{array}$ & $\begin{array}{c}\text { Mass } \\
(\mathrm{kg})\end{array}$ & $\begin{array}{c}\text { Composition } \\
(\%)\end{array}$ & $\begin{array}{c}\text { Volume } \\
\left(\mathrm{m}^{3}\right)\end{array}$ & $\begin{array}{c}\text { Composition } \\
(\%)\end{array}$ \\
\hline $\begin{array}{c}\text { Cladding } \\
\text { hulls }\end{array}$ & 2,454 & 70.3 & 2.50 & 35.7 & 3,028 & 74.5 & 0.46 & 45.1 \\
\hline $\begin{array}{c}\text { Fuel } \\
\text { Hardware }\end{array}$ & 1,037 & 29.7 & 4.50 & 64.7 & 1,037 & 25.5 & 0.56 & 54.9 \\
\hline Sum & 3,491 & 100 & 7.00 & 100 & 4,065 & 100 & 1.02 & 100 \\
\hline
\end{tabular}


Two major streams of the metal waste treatment for storage or disposal are the compaction and melting processes. The melting process has a higher volume reduction factor than the compaction method while it is a high temperature process that accompanies higher energy and cost.

$\mathrm{Zr}$ recovery from zircaloy cladding hulls corresponds to an alternative technology that can reduce the amount of high level waste and reuse expensive $\mathrm{Zr}$ metal through a recycling process.

(a) Chlorination Process

In the chlorination method, chemical reaction between metallic $\mathrm{Zr}$ and $\mathrm{Cl}_{2}$ gas is employed to recover $\mathrm{Zr}$ from the hull waste through the following equation.

$\mathrm{Zr}+2 \mathrm{Cl}_{2}(\mathrm{~g}) \leftrightarrow \mathrm{ZrCl}_{4}(\mathrm{~g})\left(331^{\circ} \mathrm{C} \leq \mathrm{T}\right) \mathrm{Eq}$.

The reaction product of $\mathrm{Zr}$ chlorination, $\mathrm{ZrCl} 4$, has a relatively low boiling point of $331^{\circ} \mathrm{C}$ compared to other oxides or chlorides. Therefore, $\mathrm{ZrCl}_{4}$ can be separated from other highly radioactive or heat generating nuclides by controlling the operation temperature. Due to the selectivity of the chlorination reaction and low operation temperature, it is expected that $\mathrm{ZrCl}_{4}$ of high purity can be obtained via the chlorination method.

(b) Electro-refining process

The electro-refining process is another candidate for managing metal wastes such as cladding hulls or hardware from spent fuels. In particular, it can offer a remarkable volume reduction of high level waste by recovering $\mathrm{Zr}$ metal,which occupies more than $98 \%$ of Zircaloy-4 cladding hulls. The basic feature of the process is analogous to that of the uranium electrorefining process, where molten salts are used in the temperature range of $450^{\circ} \mathrm{C}-850^{\circ} \mathrm{C}$. Zircaloy- 4 hull cuts are inserted in the anode basket, and $\mathrm{Zr}$ metal is electrochemically recovered on the cathode with a simultaneous anodic dissolution of $\mathrm{Zr}$ by applying a constant current or potential.

\subsubsection{Salt Waste Treatment Process}

The salt waste treatment process is divided into two parts: $\mathrm{LiCl}$ salt waste treatment and eutectic $(\mathrm{LiCl}-\mathrm{KCl})$ salt waste treatment. In the $\mathrm{LiCl}$ salt waste treatment process, Group I and II fission products involved in $\mathrm{LiCl}$ salt waste are removed by a crystallization process and then the remaining residual $\mathrm{LiCl}$ salts containing a high content of Group I/\&II fission products, such as Cs and $\mathrm{Sr}$, are immobilized by the inorganic matrix, SAP, to the ceramic waste forms. Rare earth fission products bearing eutectic salt wastes from the RAR (Residual Actinide Removal) process are treated by successive rare earth removal processes: oxygen sparging, layer separation, and vacuum distillation/condensation. Finally, the remaining rare earth oxides (or oxychlorides) are fabricated into the durable ceramic waste forms by the ZIT matrix. During each salt waste treatment process, pure $\mathrm{LiCl}$ and eutectic $(\mathrm{LiCl}-\mathrm{KCl})$ salts were recovered for reuse with a high regeneration ratio.

\subsubsection{LiCl Salt Waste Regeneration Process}

For the reuse of $\mathrm{LiCl}$ salt waste, Group I and II fission products have to be separated from the $\mathrm{LiCl}$ salt wastes. To separate Group I and II fission products, such as Cs and $\mathrm{Sr}$, a chemical agents addition method and an ionexchange method were tested [25-28]. However, the results showed that both the separation of $\mathrm{Cs}$ and $\mathrm{Sr}$ from $\mathrm{LiCl}$ molten salt via various chemical agents and ionexchange by zeolite was nearly unlikely [29]. As a result of these difficulties in separating cesium and strontium, a layer crystallization process, which uses the solubility difference of impurities between the solid (=crystal) and melt phase was introduced.

Layer crystallization is a very simple process that uses cooled plates immersed in a melt for crystal formation, where a crystal grows as a compact crystalline layer on a cooling surface. In this process impurities are concentrated in the melt phase and not in the crystal layer formed outer surface of the crystallizer. In a crystallization furnace, $\mathrm{LiCl}$ crystal is formed at the outer surface of plate-type crystallizers by a coolant. The crystallizers having $\mathrm{LiCl}$ crystal are moved to a melting furnace where the $\mathrm{LiCl}$ crystal is separated from the crystallizers by melting. Repeating these processes several times, about 80-90\% of $\mathrm{LiCl}$ containing a small amount of impurities, Group I and II fission products, can be recovered and the remaining $\mathrm{LiCl}$ in the crystallization furnace with the most impurities is transferred to the immobilization process to fabricate the final waste form.

\subsubsection{Eutectic (LiCl-KCl) Salt Waste Regeneration Process}

Rare earth elements involved in $\mathrm{LiCl}-\mathrm{KCl}$ eutectic salt waste were converted to their molten salt-insoluble precipitates in the oxidative precipitation step by an oxygen gas sparging method. After the full precipitation of these lanthanide precipitates, the eutectic salt waste is separated into two layers: the upper pure (or purified) salt layer and the lower precipitate layer. The upper pure salt layer can be physically separated from the precipitate layer, where the separated pure salt layer can be reused ( $1^{\text {st }}$ pure salt recovery). Then, the adhering eutectic salt involved in the precipitate layer is separated and recovered in the distillation/condensation step ( $2^{\text {nd }}$ pure salt recovery). Finally, all the remaining rare earth oxides or oxychlorides are fabricated as a final waste form in the immobilization step.

In the oxidative precipitation step, about $70 \mathrm{wt} . \%$ or more of the total eutectic salt waste was recovered. Fig. 7 


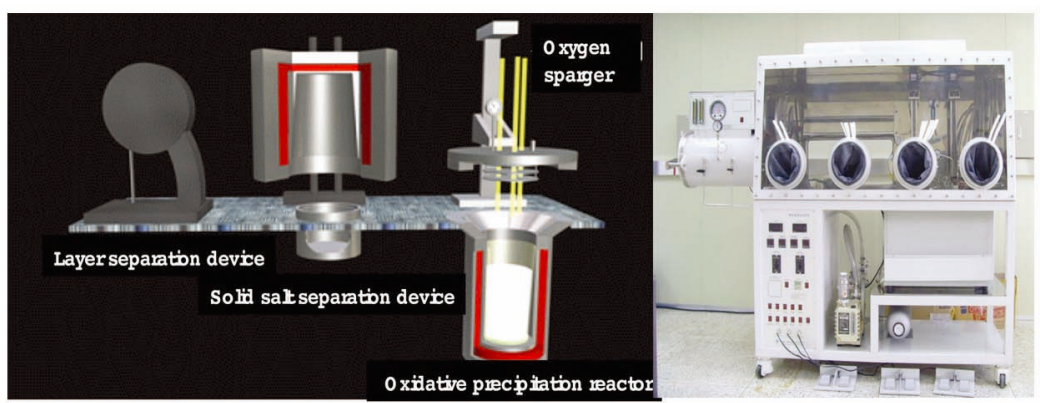

Fig. 7. Lab-scale Oxidative Precipitation Apparatus.

shows the lab-scale oxidative precipitation apparatus (maximum batch size: $4 \mathrm{~kg} / \mathrm{batch}$ ), which consisted of three parts: an oxidative precipitation reactor, a solid salt separation device and a layer separation device.

Rare earth oxide $\left(\mathrm{REO}_{2}\right.$ or $\left.\mathrm{RE}_{2} \mathrm{O}_{3}\right)$ or oxychloride ( $\mathrm{REOCl}$ ) forms were major products with the oxygen potential of a chemical reaction between rare earth and oxygen ions in a molten salt condition, where the formed rare earth oxides or oxychlorides were nearly insoluble in a eutectic molten salt resulting in precipitation. According to the analysis of the XRD patterns of the precipitates, they were a mixture of oxychlorides, i.e., $\mathrm{LaOCl}, \mathrm{PrOCl}$, $\mathrm{NdOCl}, \mathrm{SmOCl}, \mathrm{EuOCl}, \mathrm{GdOCl}$ and oxides, i.e., $\mathrm{CeO}_{2}$, $\mathrm{PrO}_{2}, \mathrm{Y}_{2} \mathrm{O}_{3}$.

The overall conversion efficiency is governed by both temperature and oxygen sparging time. Over $99 \%$ of the total conversion efficiency was obtained in the operating conditions of $750^{\circ} \mathrm{C}-12$ hour or $800^{\circ} \mathrm{C}-6$ hour

The lab-scale vacuum distillation apparatus has a single body of vaporization and condensation chamber and it makes it possible to create a temperature gradient in the chamber by using the four electric heaters and the cooling system. It is also possible to operate under a state of a closed system at a reduced pressure. Because of these characteristics, the apparatus is subjected to the force of a temperature gradient at a reduced as a closed type of system and it is possible to collect vaporized salts only in the salt collector. As a result of the distillation test, the $\mathrm{LiCl}-\mathrm{KCl}$ eutectic salt in the precipitate layer was vaporized more than $99 \mathrm{wt} \%$ and also over $99 \mathrm{wt} \%$ of the vaporized salts was recovered. During the test, carryover of the rare earth precipitates was not generated and the chemical forms of the rare earth precipitates were not changed.

\subsubsection{Resiudal Waste Solidification Process}

In order to treat salt waste for final disposal, a dechlorination approach was adapted, where metal chloride waste was de-chlorinated and thermally stabilized using the synthetic inorganic composite SAP composed of $\mathrm{SiO}_{2}$, $\mathrm{Al}_{2} \mathrm{O}_{3}$ and $\mathrm{P}_{2} \mathrm{O}_{5}$, and its resultant product was sintered with a conventional borosilicate glass to obtain a monolithic wasteform.

The rare earth precipitates from the eutectic salt waste treatment process must be immobilized to a chemically stable solid wasteform for long-term storage in a geological environment. To immobilize rare earth oxide/oxychlorides, the inorganic composition, ZIT, composed of $\mathrm{Zn}_{2} \mathrm{TiO}_{4}-$ $\mathrm{CaHPO}_{4}-\mathrm{SiO}_{2}-\mathrm{B}_{2} \mathrm{O}_{3}$ was developed.

The SAP material is prepared using a conventional sol-gel method, and then mixed and reacted with molten salt residue for 16 hours at $650^{\circ} \mathrm{C}$. The reaction product undergoes a final heat treatment step with an addition of glass frit for 4 hours at around $1150^{\circ} \mathrm{C}$ to form a durable ceramic waste form. The developed ZIT matrix consists of $\mathrm{Zn}_{2} \mathrm{TiO}_{4}(60 \mathrm{wt} \%)$ as a main inert matrix, $\mathrm{CaHPO}_{4}$ $(17.5 \mathrm{wt} \%)$ as a phosphate source for monazite and nonmetallic oxide, $\mathrm{SiO}_{2}(10 \mathrm{wt} \%)$ and $\mathrm{B}_{2} \mathrm{O}_{3}(12.5 \mathrm{wt} \%)$. The ZIT matrix is simply prepared by mixing the components and then sintering at $700^{\circ} \mathrm{C}$ To make the monolithic wasteform, the rare earth oxides waste is mixed with the ZIT matrix and sintered at $1100^{\circ} \mathrm{C}$

To realize the immobilization method, the lab-scale solidification process, which consists of crushing, pulverizing, mixing/reacting and sintering equipment, was used. Up to now, the unit equipment was developed to obtain a proper performance and their processing conditions were investigated to abstract the scale-up factors.

Table 3 shows the chemical durability of wasteforms and some physical properties for two wasteforms, SAP and ZIT. The leach-resistance of the radionuclides was comparable to other radioactive wasteforms and the wasteforms had physiochemical properties similar to silicate and phosphate glassy wasteforms [30].

\section{CONCLUSION}

KAERI has developed a pyroprocessing, non-aqueous treatment process for spent fuel treatment to recover useful materials such as uranium, plutonium, and reduce 
Table 3. Some Properties of Two Wasteforms

\begin{tabular}{|c|c|c|}
\hline Property & SAP wasteform & ZIT wasteform \\
\hline Radionuclide leach rate, $\mathrm{g} / \mathrm{m}^{2}$ day & $10^{-4}-10^{-3}$ for $\mathrm{Cs} / \mathrm{Sr}$ & $<10^{-5}$ for rare earth \\
\hline Wasteform leach rate, $\mathrm{g} / \mathrm{m}^{2}$ day & $10^{-2}$ & $10^{-3}$ \\
\hline Density, $\mathrm{g} / \mathrm{cm}^{3}$ & $2.35-2.40$ & $3.7-4.2$ \\
\hline Thermal Conductivity, W/mK & $1.1-1.4$ & 1.7 \\
\hline Thermal Capacity, J/gK & $0.96-1.07$ & 0.65 \\
\hline Glass Transition Temperature, $\mathrm{K}$ & $753-800$ & - \\
\hline Thermal Expansion Coefficient, K-1 & $3.0 \times 10^{-6}$ & \\
\hline Micro-Hardness, GPa & $4.76 \pm 0.15$ & 5.5 \\
\hline
\end{tabular}

the spent fuel volume and toxicity. Through the R\&D of the last decade, some innovative technologies, such as advanced voloxidation, high-capacity electrolytic reduction, high-throughput electrorefining with a graphite cathode, mesh-type liquid cadmium cathode electrowinning, and waste salt regeneration by a crystallization method, have been tested successfully. This advanced technology in engineering-scale will be demonstrated in an integrated inactive pyroprocess facility (PRIDE). The PRIDE will verify the performance of each item of equipment, the interaction between units, the remote operability, facility management system, and process monitoring, which will provide an overall perspective of pyroprocessing.

\section{REFERENCES}

[ 1 ] Y. J. Shin, et al., KAERI/RR-2128, (2000)

[2] S. H. Ahn, J. H. Jin and J. S. Yoon, "Development of a Tele-operated Manipulator System for Remote Handling of Spent Fuel Bundles", KNS. Vol. 35, pp 214-225, (2003)

[ 3 ] S. H. Hong and J. W. Jeon, "A Real-Time Graphic Simulator to Monitor Spent Nuclear Fuel Dismantlement Devices", Nucl. Technol. Vol. 139, pp 263-273, (2002)

[4] S.M. Jeong, J.M. Hur, S.S. Hong, D.S. Kang, M.S. Choung, C.S. Seo, J.S. Yoon, "An Electrochemical Reduction of uranium Oxide in the Advanced Spent Fuel Conditioning Process," Nucl. Technol., 162, 184, (2008)

[ 5 ] J.M. Hur, I.K. Choi, S.H. Cho, S.M. Jeong, C.S. Seo, "Preparation and Melting of Uranium from $\mathrm{U}_{3} \mathrm{O}_{8}$, , J. Alloys Compounds, 452, 23, (2008)

[6] S. Herrmann, S. Li, M. Simpson, "Electrolytic Reduction of Spent Fuel: Bench-Scale Experiment Results," J. Nucl. Sci. Technol., 44, 361, (2007)

[7] J. M. Shin and J. J. Park, "Trapping Characteristics of Cesium in Off-Gas Stream Using Fly Ash Filter", Korean J. Chem. Eng. 18(6), 1010, (2001)

[ 8 ] J. J. Park, et. al., "Development of Voloxidation Process for Treatment of LWR Spent Fuel", KAERI/RR-2840/2006, (2007)

[9] J. J. Park, et. al., "Development of Advanced Voloxidation
Process for Treatment of Spent Fuel", KAERI/RR-3212/ 2009, (2010)

[10] B. R. Westphal, J. J. Park, J. M. Shin, G.I. Park, K. J. Bateman, and D. L. Walquist, "Selective Trapping of Volatile Fission Products with an Off-Gas Treatment System", Separation Science and Technology, 43, 2695, (2008)

[11] B. H. Park, H. H. Lee, W. M. Choung, J. M. Hur and C. S. Seo, "Advanced in the ACP Facility Electrochemical Reduction Process", Nucl. Technol., Vol. 171, pp 232-246, (2010)

[12] S. D. Herrmann and S. X. Li, "Separation and Recovery of Uranium Metal from Spent Light Water Reactor Fuel Via Electrolytic Reduction and Electrorefining", Nucl. Technol., Vol. 171, pp 247-265, (2010)

[13] J. H. Lee, Y. H. Kang, S. C. Hwang, J.-B. Shim, E. H. Kim, S. W. Park, "Application of Graphite as a Cathode Material for Electrorefining of Uranium", Nucl. Technol., Vol.162, pp 135-143, (2008)

[14] S.X. Li, "Anodic Process of Electrorefining Spent Nuclear Fuel in Molten LiCl-KCl-UCl $\mathrm{UCd}_{3} / \mathrm{Cd}$ System", Proceedings of $13^{\text {th }}$ International Symposium on Molten Salts, Philadelphia, PA, May 12-17, (2002)

[15] Y.-S. Lee, C.-H. Cho, S.-H. Lee, J.-G. Kim, H.-S. Lee, "Uranium ingot casting method with Uranium deposit in a Pyroprocessing", J. Korean Radioactive Waste Soc., Vol.8, pp 85-89, (2010)

[16] T. Hijikata, T. Koyama, "Development of high temperature transport technologies for liquid cadmium in pyrometallurgical reprocess", J. Power and Energy System, Vol.3, pp 170178, (2009)

[17] Argonne National Laboratory, CMT Annual Technical Report 1987, ANL-88/19, (1988)

[18] T. Koyama, M. Iijuka, Y. Shoji, R. Fujita, H. Tanaka, T. Kobayashi, M. Tokiwai, J. Nucl. Sci. Technol. Vol. 34 (4), pp. 384-393, (1997)

[19] Argonne National Laboratory, CMT Annual Technical Report 1993, ANL-94/15, (1994)

[20] J.B. Shim, Y.J. You, S.W. Kwon, S.H. Kim, S.W. Paek, K.R. Kim, J.G. Kim, H. Chung, and D.H. Ahn, "Thermodynamic and Experimental Approaches for an Effective Recovery 
of Actinides from a Spent LiCl-KCl Salt", Proceedings of the 2008 International Pyroprocessing Research Conference, Aug. 24-27, 2008, Jeju Island, Republic of Korea, (2008)

[21] K. Kinoshita, T. Inoue, S.P. Fusselman, D.L. Grimmett, J.J. Roy, R.L. Gay, C.L. Krueger, C.R. Nabelek, and T.S. Storvick, "Separation of Uranium and Transuranic Elements from Rare Earth Elements by Means of Multistage Extraction in LiCl-KCl/Bi System", J. Nucl. Sci. Techol., 36, 189, (1999)

[22] Cassayre L, Caravaca C, Jardin R, Malmbeck R, Masset P, Mendes E, Serp J, Soucek P, Glatz JP, "On the formation of U-Al alloys in the molten LiCl-KCl eutectic", $J$ Nucl Mater, 378, 79-85, (2008)

[23] Levillain E, Gaillard F, Leghie P, Demortier A, Lelieur JP, "On the understanding of the reduction of sulfur $\left(\mathrm{S}_{8}\right)$ in dimethylformamide", J Electroanal Chem., 420, 167-177, (1997)

[24] ANSYS CFX-12.0 Solver 2008 (Cannonsburg, USA/ ANSYS:www.ansys.com)

[25] M. F. Simpson and M. L. D. Gougar, Two-Site Equilibrium Model for Ion Exchange between MonovalentCations and Zeolite-A in a Molten Salt, Ind. Eng. Chem. Res., 42, 4208-
4212, (2003)

[26] R. K. Ahluwalia, H. K. Geyer, C. Pereira, and J. P. Ackerman, Modeling of a Zeolite from Molten Salt, Ind. Eng. Chem. Res., 37, 145-153, (1998)

[27] S. Phongikaroon and M. F. Simpson, Equilibrium Model for Ion Exchange Between Multivalent Cations and Zeolite-A in a Molten Salt, AIChE, 52(5), 1736-1743, (2006)

[28] D. Lexa, Occlusion and ion exchange in the molten (lithium chloride potassium chloride alkaline earth chloride) salt zeolite 4A system with alkaline earth chlorides of calcium and strontium, and in the molten (lithium chloride potassium chloride actinide chloride) salt zeolite 4A system with the actinide chloride of uranium. Metallurgical and Materials Transactions B., 34, 201-208, (2003)

[29] H. S. Park, I. T. Kim, Y. J. Cho, M. S. Son, H. C. Eun, Removal behavior of Cs from molten salt by using zeolitic materials, J Radioanal Nucl Chem., 283, 267-272, (2010)

[30] Lee, W.E., Ojovan, M.I., Stennett, M.C., Hyatt, N.C.; Immobilization of radioactive waste in glasses, glass composite materials and ceramics, Adv. App. Ceram. 105, $1-12,(2006)$ 